\title{
Understanding Interpreting Strategies: Case Study in Consecutive Interpreting in Jokowi and Malcolm Turnbull Press Conference
}

\begin{tabular}{ll} 
& $\begin{array}{l}\text { Wikan Hastuningdyah } \\
\text { 1' }\end{array}$ \\
\hline \hline Universitas Indonesia, Indonesia
\end{tabular}

Corresponding Author: Wikan Hastuningdyah, Faculty of Cultural Science, Universitas Indonesia, Indonesia.Email: wikanhdyah@gmail.com

Copyright $\odot$ Association of Language Teachers in Southeast Asia. All rights reserved

\section{INTRODUCTION}

Interpreting and translating are activities for transferring messages from one language to another. Both are intended so that the message conveyed by the speaker or writer in the source language (SL) can be understood by the audience or reader in the target language (TL).

Although both have the same purpose, they are both conducted in different ways and in a different setting. According to the International Encyclopedia of Linguistics (2003:281) translation activities will be written (written discourse) while interpreting will be done orally (oral discourse). Other differences are the level of fidelity, time limit, and the development of translation and interpreting studies.

In the translation process, a translator can be more loyal to the message in the source language. This is due to the longer time the translator has. It is not limited within seconds. Therefore it is very possible for a translator to look for references, open a dictionary, and dig deeper information about 
the message he will deliver back in the target language. With hope, all information and references can improve readers' understanding in the target language.

The process and the nature of translation is a stark contrast with interpreting. In general, interpreting occurs directly or in one time frame. The message is delivered only once by the resource person in the source language. In addition, an interpreter is required to be able to follow the flow of the message/conversation/dialogue that takes place. Therefore an interpreter does not have a long time to divert messages from the source language to the target language.

In its efforts to translate messages from source languages to target languages, an interpreter is required to have good listening skills, has a lot of knowledge, has a good understanding of meaning, good language skills (source language and target language), and good ability to speak and utterance. Apart from these capabilities, an interpreter must also understand that the nature of interpreting works is always under pressure. An interpreter has to start speaking in the target language is usually no more than four seconds, especially in simultaneous interpreting where the interpreter must start talking when he or she has understood the message, and not wait until the sentence is finished by the speaker in the source language.

It needs to be understood, that the language transfer activities, namely translation and interpreting have their own challenges. It is undeniable that differences in language, culture, knowledge possessed by speakers and listener or reader will become obstacles in conveying messages. From the development of ongoing translation studies, experts began to express their ideas to deal with this problem. A number of tricks, techniques began to emerge, but the idea of strategy was first raised by Hönig and Kussmaul (1982), which led to the optimum solution to a translation problem.

After understanding the challenges faced by the interpreter, and knowing that there are strategies that can be used in dealing with difficulties in language transfer, then questions arise about strategies that can be used in interpreting. In practice, interpreters can apply a number of strategies that can help them overcome time constraints, limited knowledge or limited language ability.

This study will see more about the application of interpreting strategies carried out in consecutive interpreting. This study wants to show what challenges face interpreters, what strategies are chosen by interpreters, and what changes occur as a result of applying the strategy.

\section{LITERATURE REVIEW}

Pöchhaker (2004: 11) states that interpreting is a form of translation that TSa delivery can only be done once because the SL is only spoken once. This definition was obtained by Pöchhaker after understanding the interpreting criteria presented by Kade (1968) in Pöchhaker (2004). Kade mentioned that two things need to be understood in interpreting, namely;

1) Text in the SL is only delivered once, so it cannot be reviewed first or repeated again.

2) The texts in the target language are produced by interpreters in a limited time and do not have many opportunities to improve or revise what has been said.

Interpreter work is divided into two types, namely consecutive interpreting and simultaneous interpreting. Setton and Dawrant (2016: 133) explain that in consecutive interpreting, the interpreter will first listen to the message conveyed by the speaker in SL before finally being delivered again in TL. Interpreters have the time to understand the message thoroughly before he returns. In addition, interpreters are strongly encouraged to use notes to help interpreters remember messages. Consecutive interpreters are usually carried out in a number of situations, for example in negotiations and dialogue between companies or between heads of state, trials, press conferences, and so on. Technically, a SL speaker will deliver a message, at the same time an interpreter will listen and make a brief note in the form of a symbol about what was conveyed by the speaker SL. When the speaker SL stops speaking, the interpreter will re-express the message that has been delivered by the speaker using TL.

According to Moser-Mercer (1997) the strategy in interpreting is optimal action that is done consciously or automatically by an interpreter who aims to solve problems in interpreting. A similar definition is stated by $\mathrm{Li}$ (2015) that strategy is an action carried out by an interpreter to overcome problems in interpreting, such as limited capacity in processing messages, limited 
knowledge, and time. From these two definitions it can be understood that interpreters have the option to solve interpreting problems by implementing strategies. The problems in interpreting can affect the performance of the interpreter and the message delivered. For this reason, interpreters can choose appropriate strategies to overcome the challenges he/she faced.

$\mathrm{Li}$ (2015) summarizes these theories and concludes that the principle interpretation strategy, namely:

- Strategies are deliberately applied by interpreters and have goals.

- Interpreters can apply the strategy consciously or unconsciously when interpreting (Skill-based or knowledge-based).

- Some strategies occur in one language communication.

- Several strategies can be applied at the same time.

- The use of a strategy can cause a message to be lost or a reduced time

There are some researchers who develop various interpreting strategies. Li (2015) groups them into four groups of strategies as follows.

Table 1. Group of Interpreting Strategies

\begin{tabular}{llr}
\hline Strategy groups & \multicolumn{3}{l}{ Specific strategies } \\
\hline $\begin{array}{l}\text { Knowledge- } \\
\text { based strategies }\end{array}$ & $\begin{array}{l}\text { inference, resorting to world } \\
\text { knowledge, visualization, } \\
\text { personal involvement, etc. }\end{array}$ \\
\hline $\begin{array}{l}\text { Language-based } \\
\text { strategies }\end{array}$ & $\begin{array}{l}\text { chunking, } \\
\text { transcoding, restructuring, } \\
\text { reformulation, etc. }\end{array}$ \\
\hline $\begin{array}{l}\text { Meaning-based } \\
\text { strategies }\end{array}$ & $\begin{array}{l}\text { compression, } \\
\text { adaptation, addition, }\end{array}$ \\
& $\begin{array}{l}\text { omission, neutralization, } \\
\text { paraphrasing/explaining, etc. }\end{array}$ \\
\hline $\begin{array}{l}\text { Delivery-based } \\
\text { strategies }\end{array}$ & $\begin{array}{l}\text { waiting/delaying response, } \\
\text { repetition, use of prosodic } \\
\text { elements (pause distribution, } \\
\text { intonation), repair, no repair }\end{array}$ \\
& (decision for no repair) etc.
\end{tabular}

Li (2015) explained that knowledge-based strategies are interpreting strategies which count on the knowledge of the interpreter about the topics that are talked about. For example, inference is a strategy when the interpreter forgets, does not understand the message, or he/she does not hear the message. The interpreter can handle it by relying on SL knowledge and speech context. For language-based strategies, there's a strategy called chunking. The strategy is used to overcome the differentiation in the language structure between SL and TL. By applying this strategy, the interpreter can cut a speech or remarks (especially long and complicated sentences) into several simpler sentences which allows the listener to understand the message easier. Another group is meaning-based strategies, for example addition. The interpreters add information that does not exist in messages in SL, such as connecting discourse markers and rhetorical phrases, so that messages in TL sound more logical and coherent for listeners. The last group is the delivery-based strategies, for example delaying responses strategy which interpreter strategically manages pauses to set the tones and meanings in communication.

\section{METHOD}

This study is conducted in qualitative approach by Hale and Napier (2013). This method is selected to show the concept and characteristic of the strategies used in the interpretation and to analyze process and product of interpreting. The data is the 22 minutes video of joint press conference of 
PM of Australia, Mr. Malcolm Turnbull and President of Republic of Indonesia Mr. Joko Widodo (credit: 7 News Australia/Youtube). First step is to obtain the data by transcribing the video. Secondly, the data were analyzed with the models of Miles of Huberman, which is by reduction data to point out parts of the dialog which were interpreted by applying interpreting strategies. Next, the data is arranged, comparing the text in SL and TL, in tables and graph to comprehend the application of interpreting strategy and its effect on the TL meaning.

\section{RESULT AND FINDINGS}

Based on the 22 minutes joint press conference, both interpreters occupied interpreting strategies in order to deliver the message. Due to the complex structures and messages conveyed by the Australian Prime Minister, the Australian interpreter chose various strategies to deliver the messages. The strategies implemented helped her to overcome the difficulties of the speech, and the short time span. In contrary, due to the short sentences delivered by the President of Republic of Indonesia, the Indonesian interpreter did not apply too many varieties of strategies.

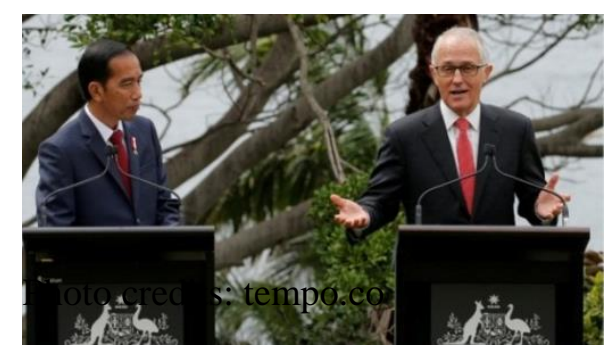

Example 1:

MT: Malcolm Turnbull,

AUS-I: Australian Interpreter

JKW: Joko Widodo

INA-I: Indonesian Interpreter

MT: Well, President Widodo (1) welcome. (2) It's been, we've had a wonderful visit. We had a very relaxed and enjoyable dinner last night at our home with (3) your wife the first lady, Ibu Iriana, and Lucy and (4) the foreign minister and defense minister. (5) And we had a walk in the Botanic Garden this morning

AUS-I: Baik, Bapak Presiden Widodo (1)selamat datang di Australia dan (2) kami sangat senang sekali dengan kunjungan anda ke sini. Dan tadi malam kita sudah melakukan makan bersama secara rileks dan sangat menyenangkan di rumah kami, bersama (3) Ibu Negara, Ibu Iriana Widodo dan Ibu Lucy, dan juga bersama (4) Ibu Menlu dan Ibu Menhan. (5) Jadi selamat datang.

MT: (6) And the warmth that you were received by the um.. all the joggers in the gardens and by some Indonesian students who were delighted to see us both shows how warm and strong the friendship between the two countries is.

AUS-I: (6) Dan betapa hangatnya bapak diterima dan disambut oleh baik pejalan kaki dan para pelari di taman Botanic tadi dan juga oleh para mahasiswa Indonesia yang ada di sini yaitu (7) menunjukan, jadi mereka senang sekali mereka untuk melihat kita berdua, dan itu menunjukan bahwa hubungan kita dan persahabatan antara dua negara kita (8) sangat hangat dan sangat erat.

Based on this transcript, there are several interpreting strategies taken by the AUS-I to deliver the message in Indonesian language. The interpreter has the knowledge that the minister of foreign affaairs of Republic of Indonesia and the minister of Defense Affair of Australia are women (4), therefore they she addressed them as 'Ibu Menlu dan Ibu Menhan'. The probability is also that both ministers are attending the press conference, and based on the information that she know beforehand she adapted the message in SL. 
There are also several meaning-based strategies chosen by the AUS-I, such as omission and addition. For the greeting (1), the PM said 'Welcome' and the AUS-I decided to add more lengthy translation to make it more natural for the Indonesian listener to 'Selamat datang di Australia'. This is considered as an addition strategy. While in another part, the AUS-I decided to omit the words (3) 'your wife' due to its clearness that the first lady of the President of Republic of Indonesia must be his wife. She acknowledged the redundancy to translate those words, and decided to say 'Ibu Negara, Ibu Iriana Widodo' instead. The AUS-I also applied another omission (5) at the end of the part by deleting 'And we had a walk in the Botanic Garden this morning' and change it by adding 'Jadi selamat datang'. The AUS-I understand the flow of the message that it is a greeting part and the message about a walk in botanic garden will be more coherent in another sentence. Therefore she ended the message by another welcome and in a period note. It is really important for an interpreter to always a message in a period instead of hanging at the end.

The AUS-I also use the language-based strategy (2) which is a parallel reformulation. The AUS-I dediced to completely change a sentences in PM saying into something that more familiar for the President of Republic of Indonesia and the Indonesians listeners. The AUS-I changes "It's been, we've had a wonderful visit" into "kami sangat senang sekali dengan kunjungan anda ke sini". Even though the literal message changed, the flow or the theme isn't. It still counts as a greeting and an expression of gratefulness. The AUS-I cannot always loyal to the message from the $\mathrm{SL}$, however the core or the purpose of the message is still the same. Another part with languagebased strategy is a restructuration. Restructuration $(\mathrm{Li}, 2015)$ is a strategy which an interpreter restructures the message by changing the orders of the message to make it more understandable and natural in target language. The AUS-I left out the information about Botanical garden (5)(6) from the first part of remark of the PM. She instead rearranged the message about the Botanical Garden in the next translated remarks. By using this strategy, the AUS-I can still deliver the same message even though in a different order.

Based on those remarks and the translation can be observed that the AUS-I also applied deliverybased strategy. The AUS-I made repetition (7) (8) to emphasis on the message that the relationship between two countries are in a good term.

Example 2:

MT: And we are working together to combat people smuggling and human trafficking in our region throughout coach chairing at the Bali process. And this year we'll launch the bali process business forum which brings government and business together to combat human trafficking.

AUS-I: Dan kedua negara kita sedang bekerja sama dalam hal pemberantasan dalam hal penyelundupan dan perdangan manusia di wilayah kita.| Salah satu caranya adalah menjadi ketua bersama di Proses Bali atau Bali Process.| Tahun ini kita akan meluncurkan forum bisnis Proses Bali,| yang akan mempertemukan pemerintah dengan para pengusaha untuk bisa memerangi perdagangan manusia|

As the AUS-I acknowledged the difference of structure in both language, she knew that it will be difficult for Indonesian listener to understand the message if she transfer the messages in English structure with its sentence complexity. Based on the example 2, the AUS-I decided to chunk the messages delivered by the PM into several simple sentences which are easier to understand. She turned two sentences remarks into three sentences and a compounded sentence. This strategy helps interpreter to sort the message, to produce a better understanding to the message for the listener.

Example 3:

JKW: Di bidang politik dan keamanan saya menyambut baik kerja sama yang telah dilakukan selama ini, baik dalam bentuk (9) two plus two atau dalam pertemuan ministerial council on law and security dengan penekanan kerjasama di bidang kerjasama pemberantasan terorisme $[. .$. 
INA-I: On politics and security our cooperation that both parties had undertaken it is through the (9) two plus two meeting between the foreign and defense ministers the ministerial counsel on law and security on emphasis on some prominent issues including counter terrorism [...]

The President of the Republic of Indonesia, Mr. Joko Widodo is known for his clear and short remarks. In this join press conference, he delivered the speech in a slow paced timing and in shorter sentences, which may not cause too many obstacles for the INA-I to deliver the message. However the INA-I still managed to apply interpreting strategies to enhance the English listener about the message conveyed by the President. On the example number 3, it shows that the INA-I elaborated more about the two plus two meeting by adding more information that the meeting is between of ministers of foreign and defense affair of both countries. This counted as an addition strategy which comes from the knowledge of the interpreter about the topic beforehand.

\section{Example 4:}

JKW: Indonesia menyampaikan apresiasi atas dukungan Australia selama keketuaan Indonesia di IORA, bersama kita ingin mewujudkan wilayah (10) lingkar laut india sebagai kawasan yang stabil dan sejahtera $[\ldots]$

INA-I: I have also appreciated Australia's support throughout Indonesia's chairmanship of IORA, together Indonesia and Australia are committed to promote stability and prosperity in (10) the region $[\ldots]$

Another example of the application of an interpreting strategy by the INA-I is the example number 4. The interpreter decided to omit 'Lingkar Laut Hindia' and not translate it into 'Indian Ocean Rim Territory' and just changed it into 'the region'. The INA-I comprehend that IORA itself is an organization for countries which located in a specific area, which is in the Indian Ocean Rim, and it is still understandable to the listener even though he did not translate the words. The INA-I take into account that they are still talking in the same topic. Therefore, the omission is not changing the meaning of the message.

After fully marking the strategies applied by both interpreters, the amount and variety of strategies are concluded as follows:

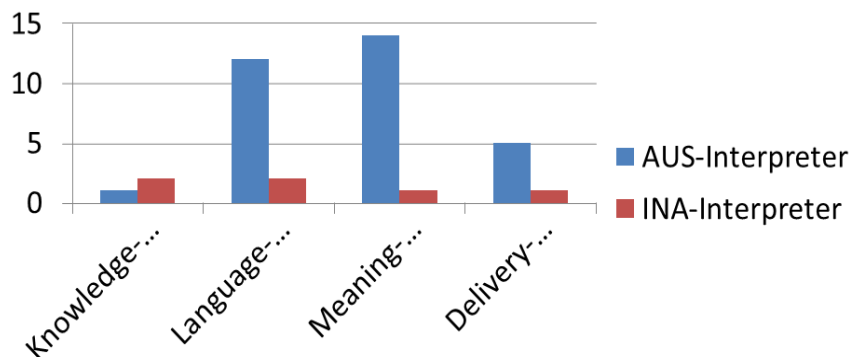

Figure1. Comparison of the amount of interpreting strategy usage

Table 2. List of strategies applied by both interpreters

\begin{tabular}{|l|c|}
\hline \multicolumn{2}{|c|}{ Strategies by AUS-Interpreters } \\
\hline World knowledge & 1 \\
\hline Parallel Reformulation & 2 \\
\hline Transcoding & 6 \\
\hline Chunking & 4 \\
\hline Omission & 6 \\
\hline Addition & 6 \\
\hline Repetition & 2 \\
\hline Delaying response & 1 \\
\hline Self repair & 2 \\
\hline Repetition & 2 \\
\hline Total & 32 \\
\hline
\end{tabular}

\begin{tabular}{|l|c|}
\hline \multicolumn{2}{|c|}{ Strategies by INA-Interpreters } \\
\hline World knowledge & 2 \\
\hline Restructuration & 2 \\
\hline Omission & 1 \\
\hline Intonation & 1 \\
\hline total & 6 \\
\hline
\end{tabular}

SALTeL Vol. 2, No. 1, 2019: $57-63$ 
The AUS-I applied more variation of strategies and more frequent than the INA-I. The most frequent strategies applied by the Australian Interpreter are the omission, addition and transcoding. The complexity of the sentences and the time span pushed the AUS-I to use various strategies in order to deliver the most important messages. As it is stated before that the level of loyalty to the message in interpreter is not the same as in written translation, and the AUS-I did her best to deliver the key message of the speech with the help of interpreting strategies.

Based on the analysis above, it can be observed that strategies are crucial tool for interpreters to deliver the message to TL. By implementing strategies, the interpreters can also deliver the message better. They restructure the sentences based on TL grammar, and adapt terminologies or expression in TL culture. Therefore, it can enhance TL listener understanding of the message.

\section{CONCLUSION}

Interpreting strategies are developed in order to overcome interpreting problems such as the time and knowledge or reference limit. In this study, it is concluded that both of interpreters applied strategy for the joint press conference. Most frequent strategies applied by both of interpreters are transcoding, omission and addition. Those strategies are chosen due to their understanding of the difficulty of the speech and the short time span. Moreover, the translated messages in TL are still conveying the same message to the original messages in SL. Therefore, the usage of strategies in this consecutive interpreting is deemed effective. As a suggestion, the next researcher who wants to study about strategies of interpreting can conduct the application of the strategies in simultaneous interpreting or analyzing specifically on the quality of the message after strategies are applied on it.

\section{References}

Chapelle, C. A. (2013). The Encyclopedia of applied linguistics. United Kingdom: Chichester.

Frawley, W. J. (2003). International encyclopedia of linguistics Vol. 1. Oxford: Oxford University Press.

Gile, D. (2009). Basic concept and models in interpreter and translator training (revised edition). Amsterdam: John Benjamins Publishing.

Hale, S., \& J, N. (2013). Research method in interpreting. London: Bloomsbury.

Herbert, J. (The Interpreter's handbook). 1952. Geneve: Universeite de Geneve - Faculte Des Lettres Ecole D'Interpretes.

Hönig, H. G. (1982). Strategie der Übersetzung. Tübingen: G. Narr.

Jones, R. (1998). Conference interpreter explained. Manchester: St. Jerome Publishing.

Li, X. (2015). Putting interpreting strategies in their place. Fédération des Traducteurs (FIT) Revue Babel. 61:2, 170-192. DOI 10.1075/babel.61.2.02li .

Moser-Mercer, B. (1996). Quality in interpreting: some methodological issues. The Interpreter's Newsletter 7, 43-55.

Moser-Mercer, B. (1997). The expert-novice paradigm in interpreting research. Fleischmann E., Hrsg, Translationsdidaktik: Grundfragen des Ubersetzungswissenschaft, 255-261.

Pöchhacker, F. (2004). Introducing interpreting studies. New York: Routledge.

Seleskovitch, D. (1978). Interpreting for international conferences. Washington DC: Peen and Booth.

Setton, R. a. (2016). Conference interpreting: a complete course. Amsterdam: John Benjamin Publishing. 